\title{
PEMBANGKIT SINYAL SPWM UNTUK MULTILEVEL INVERTER SATU FASA LIMA TINGKAT BERBASIS MIKROKONTROLER AT-Mega32
}

\author{
Baqrafi Aswida Yomahudaya, Tole Sutikno \\ Program Studi Teknik Elektro, Fakultas Teknologi Industri, Universitas Ahmad Dahlan \\ Kampus III, Jln. Prof. Dr. Soepomo,S.H. Umbulharjo, Yogyakarta 55161 \\ e-mail: baqrafi@gmail.com, tole@ee.uad.ac.id
}

\begin{abstract}
Multilevel inverter presents to fix the existing inverter as the voltage converter from $D C$ into AC. Improvements made to produce high quality output with low switching frequency. There are three types of multilevel inverters, namely: diode-clamped, fliying capacitor, and a full bridge type. The multilevel full bridge inverter type has more advantages than other types. Because of its simple construction and controll. The most used modulation technique for multilevel inverter is the Sinusoidal Pulse Width Modulation (SPWM) technique, because it has the advantage of generating a low harmonic distortion. The SPWM technique for switching divided into bipolar, unipolar, and multi-carrier. The multi-carrier SPWM switching method can reduce the switching frequency. Determination of control signal modulation technique for switching is very important and it affects to the reliability of the multilevel inverter circuit. In this study. The SPWM signal generator for the multilevel inverter using the multi-carrier method has been designed. This method was conducted by comparing two sine waves as the reference signal and two triangular waves as the carrier signal. The reference and the carrier signal were generated by ATmega32 microcontroller. The output of the reference signal and the 8-bit carrier signal from the microcontroller converted into an analog signal using the resistor network $R-2 R$ ladder. The modulation of the reference and the carrier signal was completed by using the Op-Amp LM311. The modulation generates several PWM signal as the control signal for a major component of multilevel inverter single phase with a five level approach. The results obtained has succesfully help to design a SPWM signal generator for the single phase five level multilevel inverter that was based on the ATmega32 microcontroller. Microcontroller programming has managed in generating the sine and triangle signal, as well as obtaining the PWM signal through the comparator circuit.
\end{abstract}

Keywords: multilevel inverter; SPWM multi-carrier; ATmega32 microcontroller

\begin{abstract}
Abstrak
Multilevel inverter hadir untuk memperbaiki inverter yang sudah ada sebagai pengubah tegangan DC menjadi AC. Perbaikan dilakukan untuk menghasilkan output yang memiliki kualitas tinggi dengan frekuensi switching yang rendah. Terdapat tiga tipe multilevel inverter yaitu: diodeclamped, fliying capacitor, dan tipe jembatan penuh. Multilevel inverter tipe jembatan penuh memiliki keunggulan dibandingkan tipe lain karena konstruksi dan pengaturan/kendalinya yang sederhana. Teknik modulasi yang banyak digunakan untuk multilevel inverter adalah menggunakan teknik Sinusoidal Pulse Width Modulation (SPWM) karena kelebihannya dalam yaitu menghasilkan gangguan harmonisa yang rendah. Teknik SPWM untuk switching terbagi menjadi bipolar, unipolar, dan multi-carrier. Metode switching SPWM mutli-carrier dapat menurunkan frekuensi switching. Penentuan teknik modulasi sinyal kendali untuk switching sangat penting dan berpengaruh pada keandalan rangkaian multilevel inverter.Pada penelitian ini telah dirancang pembangkit sinyal SPWM untuk multilevel inverter menggunakan metode multi-carrier. Metode ini dilakukan dengan membandingkan dua gelombang sinus sebagai sinyal reference (referensi) dan dua gelombang segitiga sebagai sinyal carrier (pembawa). Sinyal referensi dan sinyal pembawa tersebut dibangkitkan dengan mikrokontroler ATmega32. Keluaran sinyal referensi dan sinyal pembawa 8-bit dari mikrokontroler diubah menjadi sinyal analog dengan jaringan ladder resistor R-2R. Modulasi sinyal referensi dan sinyal pembawa dilakukan dengan menggunakan Op-Amp LM311. Hasil modulasi menghasilkan sinyal PWM sebagai sinyal
\end{abstract}


Jurnal IImu Teknik Elektro Komputer dan Informatika (JITEKI)

Vol. 3, No. 2, Desember 2017

kendali komponen utama multilevel inverter satu fasa dengan pendekatan lima tingkat. Hasil yang didapat telah berhasil merancang pembangkit sinyal SPWM untuk multilevel inverter satu fasa lima tingkat berbasis mikrokontroler ATmega32. Pemrograman mikrokontroler telah berhasil membangkitkan sinyal sinus dan segitiga, serta memperoleh sinyal PWM melalui rangkaian pembanding (komparator).

Kata kunci: multilevel inverter; SPWM multi-carrier; mikrokontroler ATmega32

\section{Pendahuluan}

Sekarang ini banyak penelitian mengenai teknologi inverter dengan memperhatikan output yang dihasilkan agar memiliki kualitas yang lebih baik. Salah satu penelitian yang sedang banyak dilakukan yaitu mengenai multilevel inverter. Multilevel inverter banyak dikembangkan karena kemampuannya untuk membangkitkan sinyal output kualitas tinggi dengan frekuensi switching yang rendah.

Terdapat tiga topologi multilevel inverter yaitu: diode-clamped, fliying capasitor, dan tipe jembatan penuh [1]. Multilevel inverter tipe jembatan penuh memiliki keunggulan lebih dibandingkan yang lain karena konstruksi dan pengaturan/kendalinya yang sederhana. Teknik modulasi dan strategi pengendalian untuk rangkaian multilevel inverter dikategorikan menjadi beberapa jenis, diantaranya: multilevel sinusoidal pulse width modulation (SPWM), multilevel selective harmonic elimination, dan space-vector modulation (SVM) [2]. Teknik modulasi SPWM memiliki keunggulan yaitu rendahnya distorsi harmonik pada tegangan keluaran yang dihasilkan.

Teknik modulasi SPWM adalah teknik modulasi dengan membandingkan antara gelombang sinusoida sebagai sinyal referensi dan gelombang segitiga sebagai sinyal pembawa (carrier) untuk memperoleh sinyal PWM yang digunakan pada proses switching. Teknik SPWM untuk switching terbagi menjadi: SPWM bipolar switching, SPWM unipolar switching, dan SPWM multi-carrier switching [3]. Dalam penelitian yang telah banyak dilakukan, metode SPWM multicarrier switching dapat menurunkan frekuensi switching sehingga dapat menurunkan rugi-rugi dalam proses switching. Pada penelitian ini akan merancang rangkaian hardware pembangkit sinyal SPWM dengan teknik multi-carrier untuk multilevel inverter satu fasa lima tingkat.

\section{Metode Penelitian}

\subsection{Blok Diagram Perancangan Sistem}

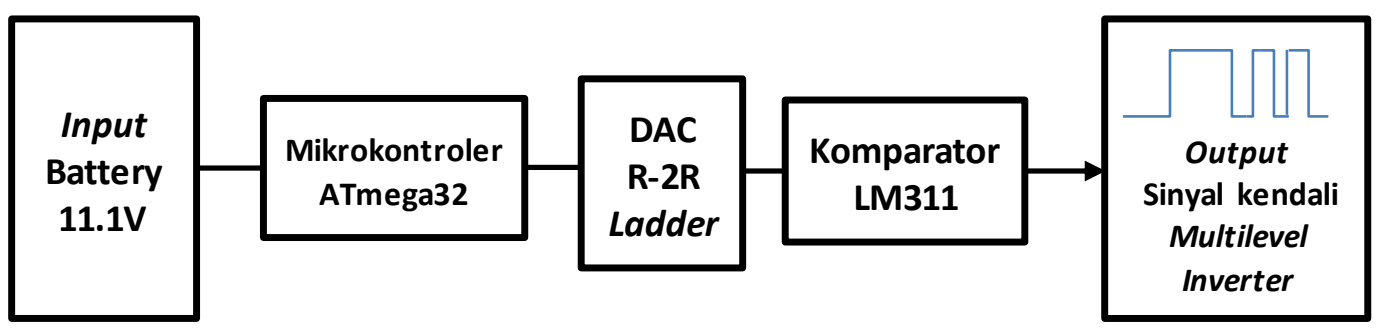

Gambar 1. Blok diagram perancangan sistem

Gambar 1 menunjukkan sistem ini menggunakan suplai battery $11.1 \mathrm{~V}$ sebagai sumber tegangan untuk rangkaian minimum sistem ATmega32. Minimum sistem ATmega32 difungsikan sebagai pembangkit sinyal referensi dan sinyal pembawa. Sinyal yang dibangkitkan terdiri dari dua sinyal sinus dan dua sinyal segitiga. Keluaran sinyal referensi dan sinyal pembawa 8-bit dari mikrokontroler diubah menjadi sinyal analog dengan jaringan ladder resistor R-2R. Modulasi sinyal referensi dan sinyal pembawa dilakukan dengan menggunakan Op-Amp LM311. Metode yang digunakan pada penelitian ini adalah SPWM multi-carrier dengan perbandingan antara gelombang referensi dan sinyal pembawa ditunjukkan pada Gambar 2. 
Jurnal IImu Teknik Elektro Komputer dan Informatika (JITEKI)

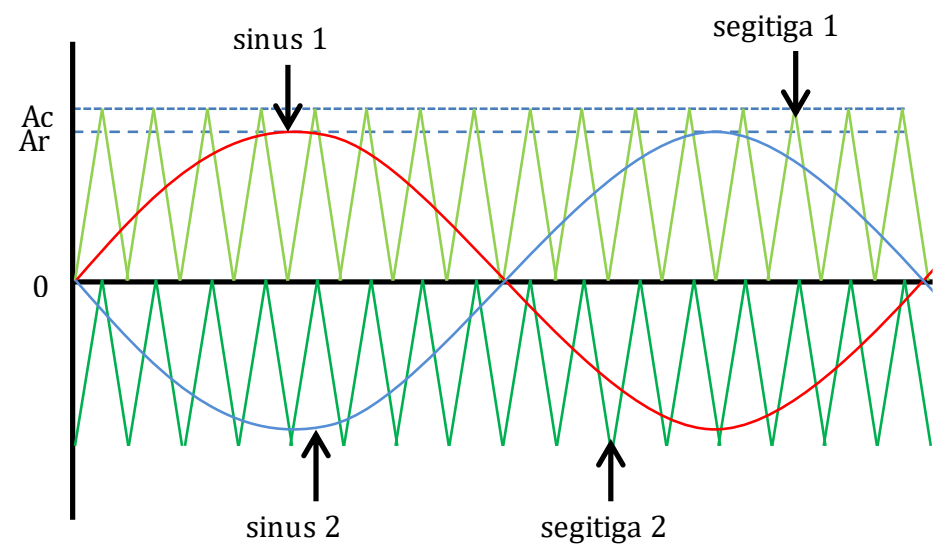

Gambar 2. Metode SPWM multi-carrier untuk multilevel inverter satu fasa 5 tingkat

Mikrokontroler ATmega32 yang difungsikan sebagai pembangkit sinyal terpasang pada rangkaian minimum sistem yang terdiri dari dua minimum sistem yaitu: minimum sistem 1 sebagai pembangkit gelombang sinus dan minimum sistem 2 sebagai pembangkit gelombang segitiga.

\subsection{Pembangkitan Sinyal Analog}

\subsubsection{Pembangkitan Gelombang Sinus}

Pembangkitan gelombang sinus dilakukan dengan pemrograman pada chip mikrokontroler ATmega32. Diagram alir pemrograman mikrokontroler ATmega32 sebagai pembangkit sinyal sinus ditunjukkan pada Gambar 3.

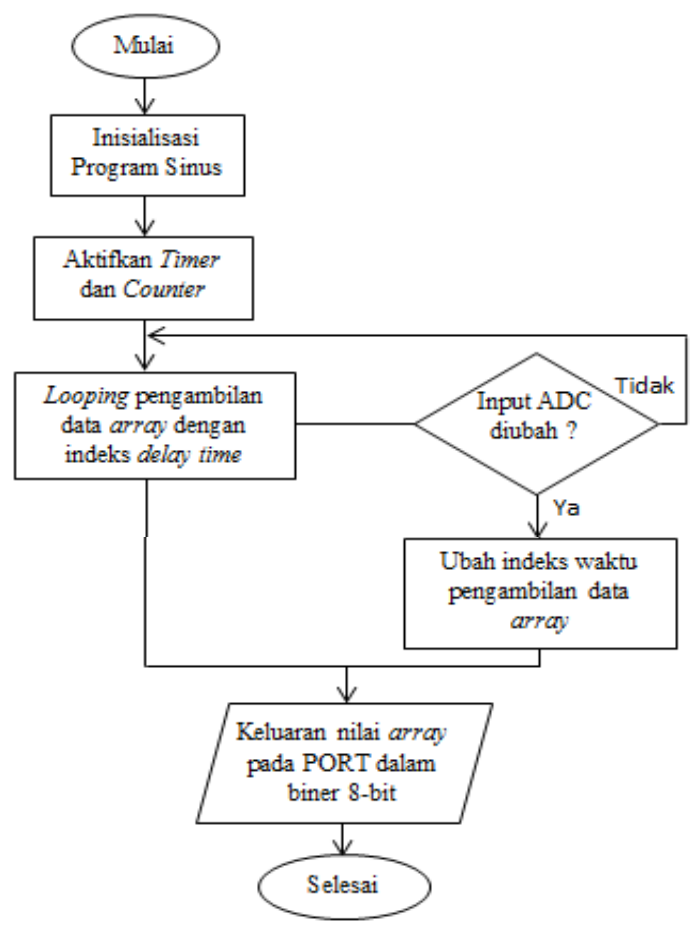

Gambar 3. Diagram alir program pembangkit gelombang sinus 
Jurnal IImu Teknik Elektro Komputer dan Informatika (JITEKI)

Vol. 3, No. 2, Desember 2017

\subsubsection{Pembangkitan Gelombang Segitiga}

Pembangkitan gelombang segitiga dilakukan dengan pemrograman pada chip mikrokontroler ATmega32. Diagram alir pemrograman mikrokontroler ATmega32 sebagai pembangkit sinyal segitiga ditunjukkan pada Gambar 4.

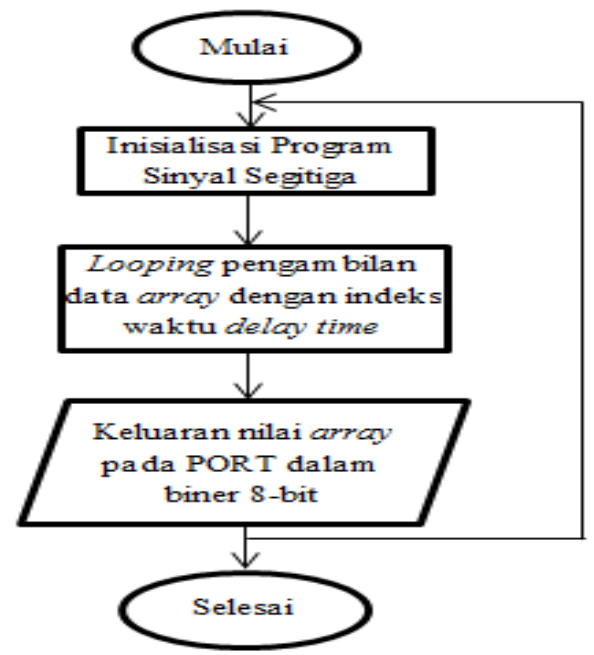

Gambar 4. Diagram alir program pembangkitan gelombang segitiga

Algoritma dari program pembangkitan gelombang sinus dan segitiga dilakukan melalui:

1. Penentuan nilai batas $\mathrm{Vpp}$ (Volt peak to peak)

2. Penentuan resolusi yang akan digunakan

3. Penentuan nilai-nilai untuk mengisi data array (sesuai dengan resolusi) yang mewakili level amplitudo sinyal analog.

4. Perhitungan nilai indeks waktu pemanggilan setiap data array (menentukan frekuensi gelombang)

5. Pemanggilan data array dengan indeks waktu yang telah diketahui dalam bentuk perulangan.

Setelah pemrograman dilakukan, dan menghasilkan sinyal 8-bit dari PORT mikrokontroler ATmega32 yang digunakan, maka selanjutnya adalah mengkonversi sinyal digital menjadi sinyal analog dengan menggunakan rangkaian Digital to Analog $R-2 R$ ladder.

\subsection{Rangkaian pembanding}

Setelah sinyal analog yaitu sinyal referensi dan sinyal pembawa dibangkitkan, maka selanjutnya dilakukan perbandingan antara sinyal-sinyal tersebut sesuai dengan metode yang digunakan. Langkah-langkah pembandingan untuk memperoleh sinyal kendali rangkaian multilevel inverter satu fasa lima tingkat dilakukan berdasarkan blok diagram perbandingan sinyal metode SPWM multi-carrier yang ditunjukkan pada Gambar 5.

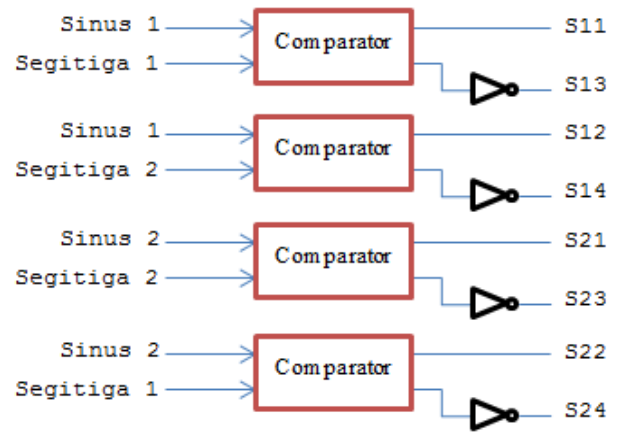

Gambar 5. Diagram blok komparator 
Jurnal IImu Teknik Elektro Komputer dan Informatika (JITEKI)

Vol. 3, No. 2, Desember 2017

\section{Hasil dan Pembahasan}

Rangkaian pembangkit sinyal kendali untuk rangkaian multilevel inverter satu fasa lima tingkat yang dirancang kemudian dilakukan pengamatan unjuk kerja. Pengamatan dilakukan dengan mengamati sinyal referensi berupa gelombang sinusoida dan sinyal pembawa berupa gelombang segitiga sebagai masukan yang akan dibandingkan melalui rangkaian pembanding. Hasil keluaran yang diperoleh berupa sinyal kendali (sinyal PWM) sebagai sinyal kendali (switching). Pengujian dan pengamatan sinyal menggunakan alat Digital Oscilloscope/Picoscope.

\subsection{Pembangkitan Sinyal Analog}

Pembangkitan sinyal analog bermula dari pemrograman yang diberikan pada chip mikrokontroler ATmega32 untuk dieksekusi. Pembagkitan sinyal analog terdiri dari pembangkitan gelombang sinusoida (sinyal sinus 1 dan sinus 2) sebagai sinyal referensi dan pembangkitan gelombang segitiga (segitiga 1 dan segitiga 2 ) sebagai sinyal pembawa.

Keluaran mikrokontroler ATmega32 berupa sinyal digital yang berfariasi sebagai representasi nilai pada data array yang dianggil satu-persatu sehingga terjadi perbedaan level tegangan. Sinyal digital keluaran mikrokontroler ATmega32 selanjutnya dikonversi menjadi sinyal analog dengan menggunakan rangkaian DAC R-2R Ladder.

\subsubsection{Pembangkitan Sinyal Referensi}

Sinyal referensi terdiri dari sinus 1 dan sinus 2 . Hasil pengamatan sinyal digital keluaran PORT mikrokontroler ATmega32 yang telah diprogram ditunjukkan pada Gambar 6 dan hasil konversi menggunakan rangkaian DAC R-2R Ladder ditunjukkan pada Gambar 7. PORT yang digunakan pada pembangkitan sinyal referensi (pada minimum sistem 1) adalah PORT D dan PORT B.

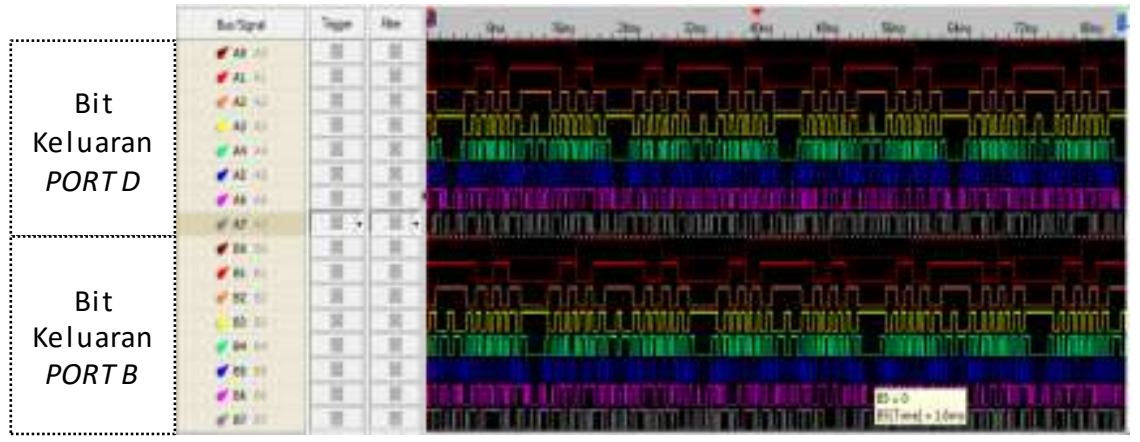

Gambar 6. Sinyal digital sinus 1 dan sinus 2

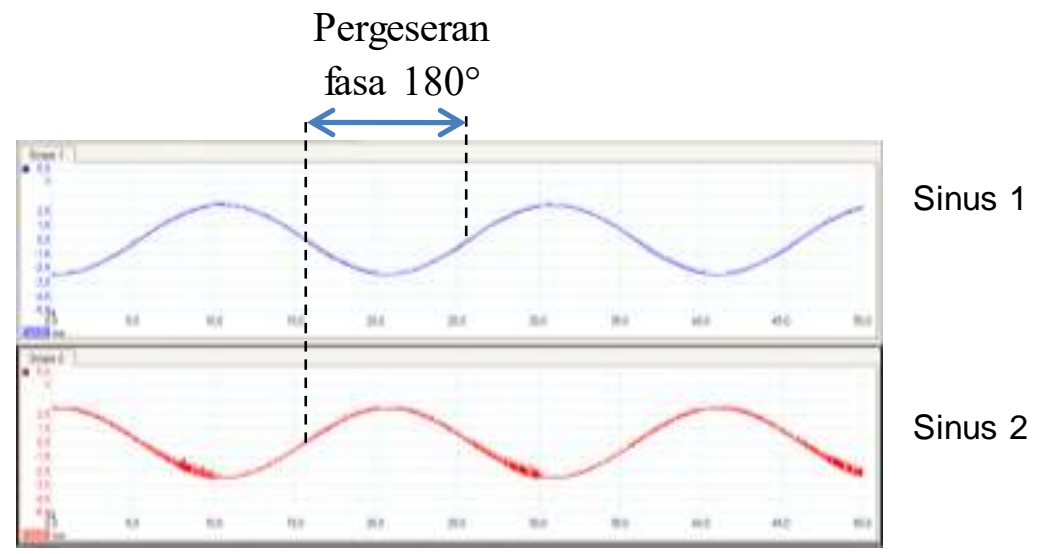

Gambar 7. Sinyal analog sinus 1 dan sinus 2

Pada penelitian ini gelombang sinusoida dapat datur dengan menggunakan potensiometer untuk mengatur frekuensi secara manual. Karena gelombang sinusoida digunakan sebagai sinyal 
Jurnal IImu Teknik Elektro Komputer dan Informatika (JITEKI)

Vol. 3, No. 2, Desember 2017

referensi, maka pengaturan frekuensi nantinya berpengaruh pada keluaran (output) rangkaian multilevel inverter. Gambar gelombang sinusoida dengan frekuensi $150 \mathrm{~Hz}$ ditunjukkan pada Gambar 8.

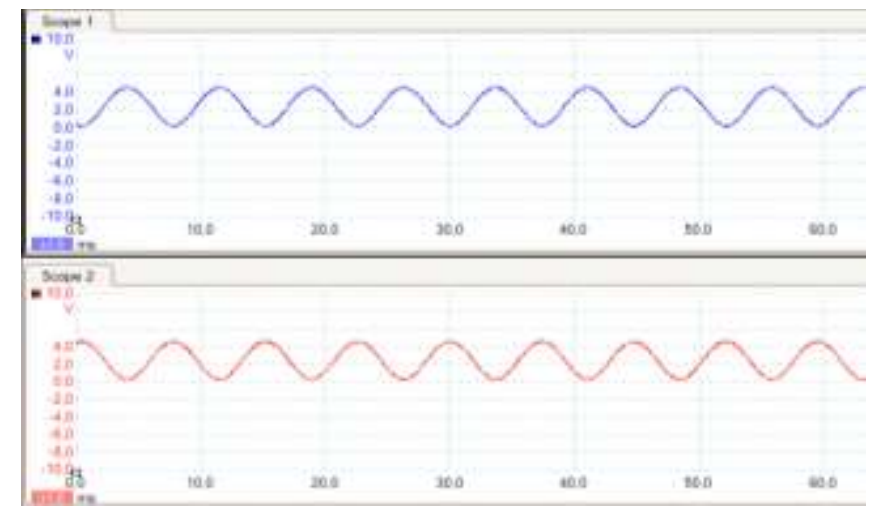

Sinus 1

Sinus 2

Gambar 8. Gelombang sinus dengan frekuensi $150 \mathrm{~Hz}$

\subsubsection{Pembangkitan Sinyal Pembawa}

Sinyal Pembawa terdiri dari segitiga 1 dan segitiga 2. Hasil pengamatan sinyal digital keluaran PORT mikrokontroler ATmega32 yang telah diprogram untuk membangkitkan gelombang segitiga ditunjukkan pada Gambar 8 dan hasil konversi menggunakan rangkaian DAC R-2R Ladder ditunjukkan pada Gambar 9. PORT yang digunakan pada pembangkitan sinyal referensi (pada minimum sistem 2) adalah PORT B dan PORT D.

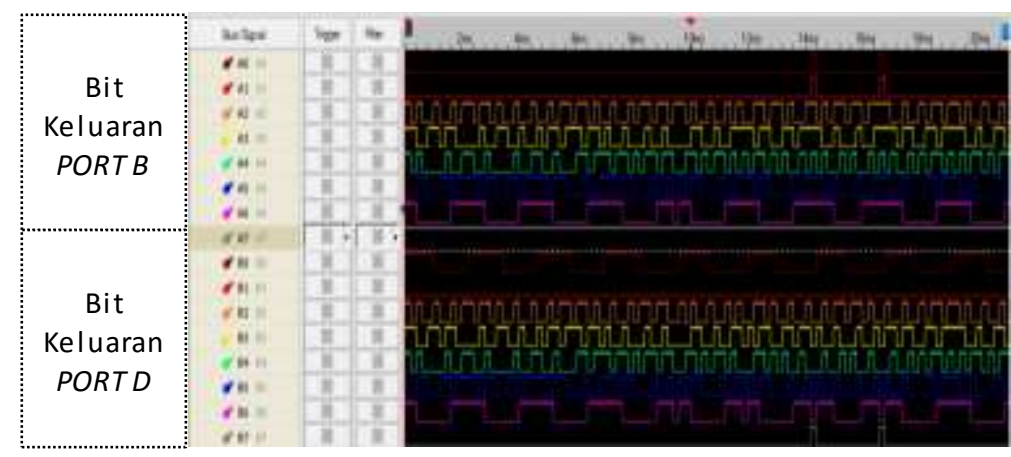

Gambar 9.Sinyal digital segitiga 1 dan segitiga 2

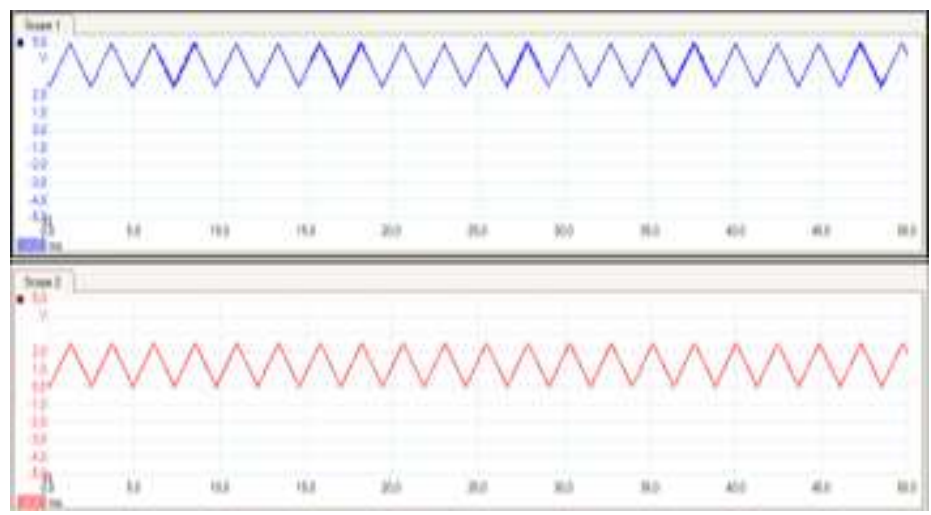

Segitiga 1

Segitiga 2

Gambar 10. Sinyal analog segitiga 1 dan segitiga 2 
Jurnal IImu Teknik Elektro Komputer dan Informatika (JITEKI)

Vol. 3, No. 2, Desember 2017

\subsection{Hasil Modulasi Sinyal SPWM Multi-Carrier}

Setelah sinyal analog diperoleh, maka selanjutnya dilakukan perbandingan dengan rangkaian pembanding yang terdiri dari rangkaian 4 unit Op-amp LM311. Gambar rangkaian hardware pembanding ditunjukkan pada Gambar 11.

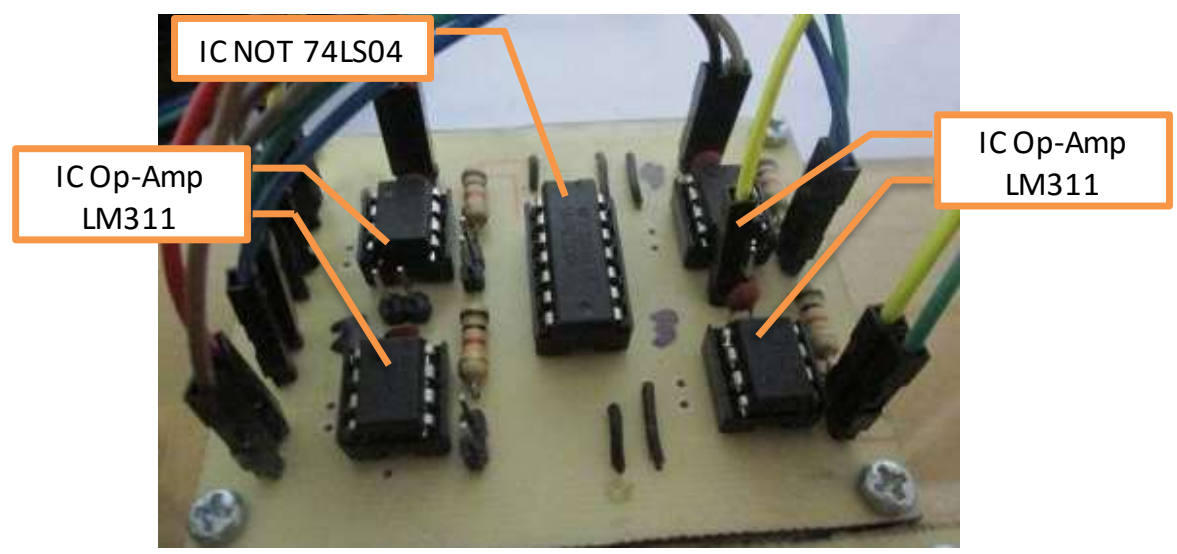

Gambar 11. Rangkaian pembanding dengan Op-Amp LM311 dan IC NOT 74LS04

Sinyal yang dibandingkan telah dihubungkan sesuai dengan blok diagram perbandingan pada metode penelitian. Hasil yang diperoleh berupa sinyal PWM untuk switching komponen utama rangkaian multilevel inverter (MOSFET, IGBT, transistor atau thyristor).

Pengujian dilakukan pada setiap hasil perbandingan pada komparator LM311 yang berjumlah 4 unit. Komparator diberi nomor untuk memudahkan dalam pengamatan.

1. Komparator 1 membandingkan Sinus 1 dan Segitiga 1

2. Komparator 2 membandingkan Sinus 1 dan Segitiga 2

3. Komparator 3 membandingkan Sinus 2 dan Segitiga 2

4. Komparator 4 membandingkan Sinus 2 dan Segitiga 1

Gambar hasil dari masing-masing perbandingan komparator ditunjukkan pada Gambar 12, Gambar 13, Gambar 14, Gambar 15. Masing-masing sinyal PWM difungsikan sebagai sinyal kendali dengan kode komponen switching "S".

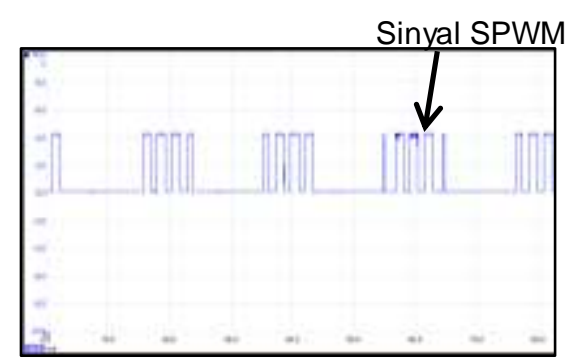

(a)

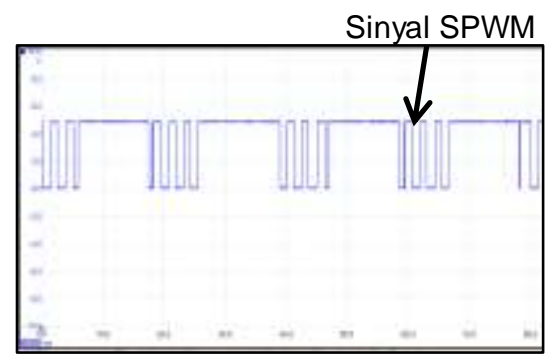

(b)

Gambar 12. Hasil sinyal komparator 1 (a) non-inverting, (b) dengan IC NOT digunakan untuk switching S11 (+) dan S13 (-) 
Jurnal IImu Teknik Elektro Komputer dan Informatika (JITEKI)

Vol. 3, No. 2, Desember 2017

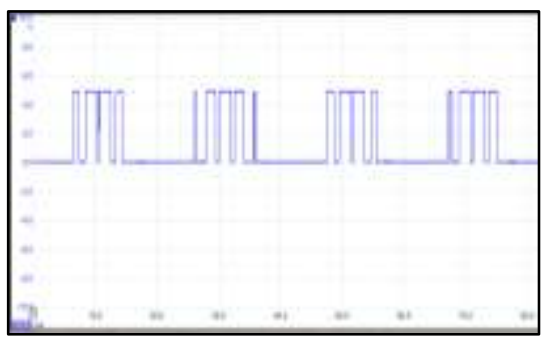

(a)

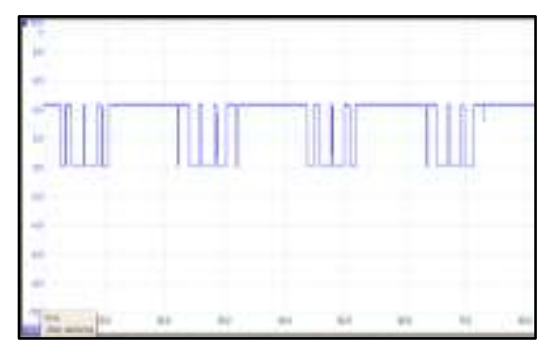

(b)

Gambar 13. Sinyal komparator 2 (a) non-inverting, (b) dengan IC NOT Digunakan untuk switching S12 (-) dan S14 (+)

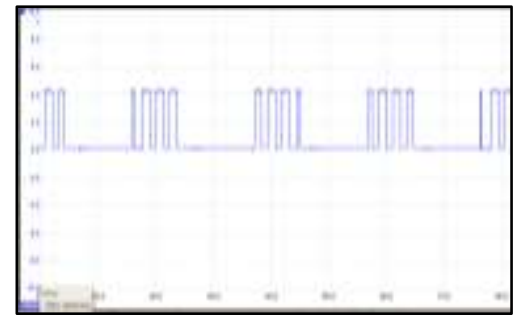

(a)

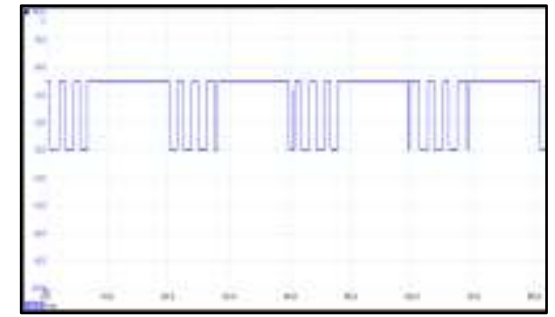

(b)

Gambar 14. Sinyal komparator 3 (a) non-inverting, (b) dengan IC NOT digunakan untuk switching S21 (+) dan S23 (-)

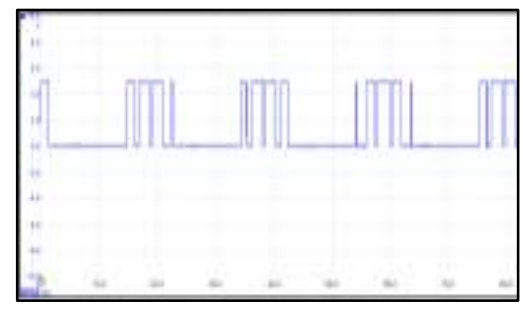

(a)

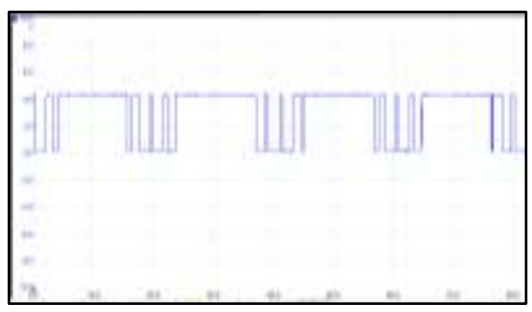

(b)

Gambar 15. Sinyal komparator 4 (a) non-inverting, (b) dengan IC NOT digunakan untuk switching S22 (-) dan S24 (+)

\section{Kesimpulan}

Komponen dan unit yang dibutuhkan untuk merancang rangkaian pembangkit sinyal Sinusoidal Pulse Width Modulation (SPWM) multi-carrier untuk multilevel inverter satu fasa lima tingkat yaitu; rangkaian mini system ATmega32, rangkaian DAC R-2R Ladder, dan rangkaian Pembanding menggunakan Op-Amp LM311. Program mikrokontroler telah berhasil dibangun untuk membangkitkan sinyal sinus dengan frekuensi $50 \mathrm{~Hz}$ sebagai sinyal referensi dan sinyal segitiga dengan frekuensi $400 \mathrm{~Hz}$ sebagai sinyal pembawa. Telah berhasil dibuat rangkaian pembanding untuk memperoleh sinyal kendali rangkaian multilevel inverter satu fasa lima tingkat dengan metode SPWM multi-carrier yang membandingkan dua sinyal sinus dan dua sinyal segitiga.

\section{Referensi}

[1] A. Warsito, M. Facta, E.A.T.., 2007. Inverter Multi Level Tipe Jembatan Satu Fasa Tiga Tingk at Dengan Mikrokontroler AT89S51. , 28(2).

[2] Rodríguez, J. et al., 2002. Multilevel Inverters : A Survey of Topologies , Controls, and 
Jurnal IImu Teknik Elektro Komputer dan Informatika (JITEKI)

Vol. 3, No. 2, Desember 2017

Applications. , 49(4), pp.724-738.

[3] Deshmukh, V.M. \& Jadhav, M.V.L., 2015. PF and THD Measurement for Power Electronic Converter. , 3(1), pp.11-16.

[4] Khasan, A., 2008. Sistem Kendali Inverter SPWM 1 Fase Berbasis Mikrokontroler AT89S51, Yogyakarta

[5] Kurniawan, D., 2013. Generator Sinus Menggunakan Mikrokontroler ATmega8. Available at: http://dwikurniawan06. blogspot.co.id/2013/08/generator-sinus-menggunakan.html.

[6] Rahayu, E. (2014). Pengenalan CodeVision AVR - Immersa Lab. Retrieved December 20,2016, from http://www.immersa-lab.com/pengenalan-codevision-avr.htm

[7] ATMEL, Datasheet Atmega32

[8] TEXAS INSTRUMENTS, 2003. Datasheet LM311. , (September 1973).

[9] Vijayalakshmi, G. (2015). Development of multi carrier PWM technique for five level voltage source inverter. Advanced Engineering and Applied Sciences: An International Journal.

[10] Zope, P.H. et al., 2012. Design and Implementation of carrier based Sinusoidal PWM Inverter. , 1(4), pp.230-236. 